\title{
Gyro failures worry NASA
}

\section{Washington}

THE failure of two of the six gyroscopes that keep the Hubble Space Telescope pointing at targets under observation is causing a major headache for the US National Aeronautics and Space Administration (NASA). Further failures could force the agency to launch an emergency space shuttle mission to replace Hubble's gyros, before the first planned shuttle visit in late 1993.

The Hubble telescope was designed to use four gyros to provide accurate positioning for its scientific observations, with two backups. In addition, Hubble has three coarser backup gyros, which cannot position the telescope with sufficient accuracy to yield useful science, but should at least keep the satellite from spiralling out of control if the science gyros give out.

NASA officials were surprised but not too concerned when one of the science gyros failed last December. But a second gyro failure on 30 June has forced project managers at the Goddard Space Flight Center to produce emergency plans to rescue the telescope in case of further problems. Since then, a third gyro suffered a momentary glitch on 26 July, and although it is still working, its characteristics have changed subtly, says John Campbell, deputy associate administrator for Hubble operations at Goddard.

After the 30 June failure, NASA officials decided to run Hubble on three science gyros, rather than turn on another backup. "To our surprise, we were able to operate very well," says Campbell. One early theory was that the high solar activity since Hubble's launch could be to blame, which argued against turning on the last backup science gyro until solar activity died down. But Campbell says that NASA's experts have now ruled out solar radiation as a factor in the failures, and the last science gyro has been turned on.

Because NASA officials cannot control Hubble with two science gyros, the satellite now stands only two gyro failures away from becoming scientifically useless. After that, the failure of just one of the three coarser backup gyros could cause the telescope to be lost altogether. NASA software engineers are now working frantically on a computer program that would allow Hubble to be kept under control in this eventuality, by using the telescope's solar and gravity sensors to keep it pointing perpendicular to the Sun.

The possibility of an emergency shuttle mission to fix the gyro problem is already under active discussion. A shuttle flight is planned for 1993, to replace the telescope's solar arrays and the Wide Field/

Planetary Camera, and to install corrective optics in front of three other instruments at the base of the telescope. But little of this equipment will be ready until just before that mission, so if an earlier flight to fix the gyros becomes essential, a second visit would still be necessary.

No decision on fixing the gyro problem can be made until the reasons for the failures are identified, and, so far, no common factor to explain the two failures has been found. The December failure US NATIONAL LABORATORIES

\section{California's record attacked}

\section{Washington}

THE University of California's management of three national laboratories came under stinging attack in Congress last week, just a week after the Department of Energy (DOE) had decided to retain the California system as contractor to run the facilities (see Nature 352, 365; 1 August 1991). Among the litany of problems trotted out before a House subcommittee were the loss of $\$ 18.6$ million worth of equipment and inadequate accounting for hundreds of millions of dollars in indirect research costs.

The three laboratories, Lawrence Berkeley and Lawrence Livermore in California, and Los Alamos in New Mexico, have all been managed by the University of California for more than 40 years. But concern about the adequacy of the university's management of the laboratories had been raised in a series of reports from the congressional General Accounting Office (GAO) and by the Inspector General at the DOE, fuelling speculation that the department would seek a new contractor - at least for Lawrence Livermore and Los Alamos, home to sensitive nuclear weapons research.

This speculation was quashed by last month's decision of Secretary for Energy James Watkins to begin negotiations to extend the university's contracts. But Howard Wolpe (Democrat, Michigan), chairman of the investigations subcommittee, said that the DOE must seek changes in the university's contracts to ensure better management in future. "If the Department is unwilling to publicly commit to securing . . . these critical changes in its contracts, then it has undermined its own position going into negotiations." DOE officials say they cannot discuss details of the contracts while they are being negotiated.

Victor Rezendes, from the GAO, told the subcommittee that the university has given higher priority to defending its own patent rights than to protecting the has been traced to the electronics designed to return the gyro back to the centre of its range of movement, after being disturbed. But the second gyro failure seems to be linked to the electronics that apply power to the gyro wheel - a seemingly unrelated problem.

For Campbell, the difficulty in pinning down the problem with Hubble's gyros is a little disturbing: "If you can't find a generic flaw in the electronics, you have to assume that it was badly built. It's like a car - if you have a lemon, it's difficult to know what to do."

Peter Aldhous

federal government's interest in defencerelated technologies developed by Livermore researchers. Because in-house patent attorneys at Livermore were busy on university business, the DOE's San Francisco field office had to hire outside lawyers during 1990 to patent a laser technology called U-AVLIS (uraniumatomic vapour laser isotope separation), used in uranium enrichment.

In addition, around 100 researchers at Lawrence Berkeley were employed on research paid for by National Institutes of Health (NIH) grants, Rezendes said. Wolpe said that a letter from NIH director Bernadine Healy had informed him that much of this work did not necessarily require the facilities available at Lawrence Berkeley. Under the rules of the DOE's 'work for others' programme, national laboratories should not accept outside grants when the work could be equally well carried out in private sector laboratories.

Asked about the accounting for indirect research costs, which amounted to some $\$ 350$ million at Livermore in 1987 (more than 35 per cent of the laboratory's total funding), DOE Inspector General John Layton said "we don't know how the money's being spent".

University officials declined the invitation to testify before the subcommittee. James Kane, who has headed the university's recent discussions with the DOE, says that the university had been willing to address the specific issue of the nonstandard clauses in its management contracts. But the scope of last week's hearings was so broad that it would have been difficult to prepare an adequate testimony, he says. Kane maintains that the University of California's contracts are broadly similar to those held by the DOE's other non-profit-making contractors - the university associations that run Fermilab and the Brookhaven $\mathrm{Na}$ tional Laboratory, and the University of Chicago, which runs the Argonne National Laboratory.

Peter Aldhous NATURE · VOL $352 \cdot 8$ AUGUST 1991 